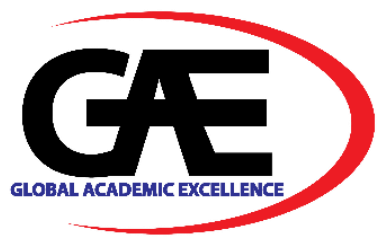

\title{
APPLICATION OF PREFERRED ISLAMIC LEGAL MAXIMS ON THE PRONOUNCEMENT OF TALAK OUTSIDE THE COURT IN MALAYSIA: A BRIEF DISCUSSION
}

\author{
Nur Sarah Tajul Urus ${ }^{1}$, Alias Azhar ${ }^{2}$ \\ 1 Kulliyyah of Syariah \& Laws, International Islamic University Sultan Abdul Halim Mu'adzam Shah (UniSHAMS), \\ 09300 Kuala Ketil, Kedah Darul Aman, Malaysia cum Universiti Utara Malaysia Ph.D candidate \\ Email: nursarah.tajulurus@gmail.com/nursarah@unishams.edu.my \\ 2 School of Law, College of Law, Government and International Studies, Universiti Utara Malaysia, 06010 Sintok, \\ Kedah Darul Aman, Malaysia \\ Email: az.alias@uum.edu.my
}

Article Info:

Article history:

Received date: 25.06 .2020

Revised date: 07.07.2020

Accepted date: 05.08.2020

Published date: 10.09.2020

To cite this document:

Tajul Uurs, N. S., \& Azhar, A. (2020). Application of Preferred Islamic Legal Maxims on The Pronouncement of Talak Outside the Court in Malaysia: A Brief Discussion. International Journal of Law, Government and Communication, 5 (20), 01-13.

DOI: $10.35631 /$ IJLGC.520001.

\begin{abstract}
:
This article discusses the application of Islamic legal maxims on the pronouncement of talak outside the court in Malaysia. The purpose of this article is to identify the preferred Islamic legal maxims by judges for divorce cases. The concept of divorce was analysed to see preferred Islamic legal maxims as an essential element in the submission of each case in order to study the role of preferred Islamic legal maxims as an argument in Islamic law and to examine the position of the writing of judgment in Islam. This study was based on a qualitative approach with two main methodologies, namely, data collection and data analysis methods. Data were gathered through document analysis and interviews over four months in 2017 in the states of Kedah and Kelantan in Malaysia. This study also examined the position and importance of judgment writing in Islamic law by interviewing two academicians and four legal practitioners to obtain information on the application of preferred Islamic legal maxims in judgments and the practice of judgment writing in divorce cases in Malaysia. Data were analysed by applying the content analysis method. This method was also used to analyse the documents obtained from the respondents to extract detailed information on the application of preferred Islamic legal maxims in divorce cases. The results of the study suggest that legal maxims play a significant role in deriving rulings and supporting
\end{abstract}

1 Kulliyyah of Syariah \& Laws, International Islamic University Sultan Abdul Halim Mu'adzam Shah (UniSHAMS), 09300 Kuala Ketil, Kedah Darul Aman, Malaysia cum Universiti Utara Malaysia Ph.D candidate. Email: nursarah.tajulurus@gmail.com/nursarah@unishams.edu.my

${ }^{2}$ School of Law, College of Law, Government and International Studies, Universiti Utara Malaysia, 06010 Sintok, Kedah Darul Aman, Malaysia. Email: az.alias@uum.edu.my 


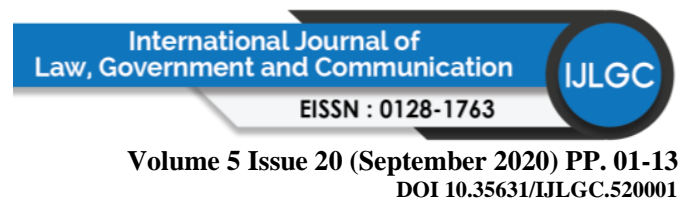

\begin{abstract}
submissions in dealing with Shariah cases. The preferred Islamic legal maxims, which contain the Maqasid al-Shariah values, must be in parallel with al-Quran and al-Sunnah. Given the prevalence of family issues today, it is hoped that society can entrust Maqasid al-Shariah in dealing with divorce cases. Cooperation between Shariah judges and lawyers helps in developing innovative elements encompassing religious and legal aspects. In this global era, the application and trend of Islamic legal maxims will have a tremendous impact on religious and institutional courts, in particular, Shariah Courts at the national level. This application is aimed at eliminating confusion among the parties involved, specifically, and the Muslim community, in general.

Keywords:

Islamic Legal Maxims, Maqasid Al-Shariah, Talaq Outside The Court, Islamic Family Law In Malaysia
\end{abstract}

\title{
Introduction
}

This paper seeks to identify the legal provisions relating to talak application procedures in the context of Malaysia. The implications of pronouncing a divorce outside the court and the factors influencing this phenomenon are also analysed. Thus, this study focuses on the application of preferred Islamic legal maxims in judgments on the pronouncement of talak outside the court. This study explains the concept of preferred Islamic legal maxims and its role in submissions in Islamic jurisprudence. The results of the study suggest that preferred Islamic legal maxims play a crucial role in deriving rulings and as supporting submissions in dealing with Shariah cases.

\section{Literature Review}

Al-Qawa'id al-Fiqhiyyah (Islamic legal maxims) is a summary of the principles that are approved by Islamic law. It was conceived by scholars to facilitate the process of referring a fiqh problem to the principles of Shariah. In addition, Islamic legal maxims can be legalised in legislation pertaining to Islamic law.

As such, Islamic legal maxims play a key role in assisting judges to solve the cases filed in Shariah Courts fairly and equitably. Islamic legal maxims help in resolving Shariah cases by providing supporting arguments for the judge's decision, assisting the judge in identifying disputed issues, facilitating the judge's decision on issues for the judgment to be fair, serving as an istinbāt method of law for issues that do not have clear legal resources, assisting in handling the demand of jointly acquired property or matrimonial assets, and helping the judge identify the parties to be made responsible for proving an issue in the Shariah Court.

Furthermore, mastering the Islamic legal maxims facilitates a person in memorising, examining, and controlling the excessive jurisprudence of fiqh in fiqh science. A unique feature of Islamic Shariah is murünah (flexibility), which refers to its suitability for people of any age, as every phase of life is subjected to various changes in many life aspects and also its applicability at all times regardless of the changes that take place in any era.

However, Islamic law is not tied to texts literally and explicitly, but it must be aligned with Islamic principles and legal maxims to address the problems of the ummah and adapt to the passage of time. Therefore, the application of Islamic legal maxims does not intend to exclude 


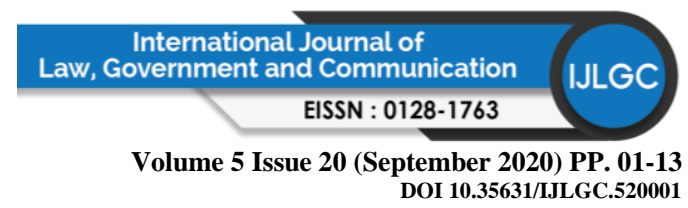

the Qur'anic verses and Hadiths. Instead, it is done to manage and guide religious and human affairs to adapt to the specific situation and time for the benefit of the people so as to achieve the Maqasid al-Shariah (objectives of the Shariah).

The previous work by Rohani binti Desa (2012) studied the application of one of the Islamic legal maxims, namely the al-Darurah method in health services in Malaysia. This method relates to the concept of Jalb al-Maslahah and Daf'ul al-Madarrah. The study looked at the elements of al-Darurah in health services and laws, as well as the policies applied by the Ministry of Health Malaysia $(\mathrm{MoH})$. The researcher assessed the accuracy of the laws and policies adopted by the MoH against the Islamic legal maxim of al-Darurah, which contains the methods of al-Masyaqqah Tajlīb al-Taysīr and al-Darar Yuzāl. The researcher used two forms of research, namely library and field research, to achieve the objective of the study. The results show that the majority of health service practices in Malaysia are based on the laws and policies adopted by the MoH which are in line with the al-Darurah method. However, the study focused on the Islamic legal maxim of al-Darurah only and discussed the laws and policies adopted explicitly by the MoH.

Subsequently, the study by Zubir (2008) examined Islamic legal resources and fiqh methods and their relationship in resolving current issues. The study investigated the fundamental development of fiqh and how Islamic legal maxims play a role in solving current issues. The research was done by reviewing past studies of numerous scholars. The results of the study show that although Islamic legal maxims cannot be used as a source of al-Quran and Hadith, these maxims are vital in guiding the mujtahid by ensuring that the development of fiqh does not deflect from the foundation of Islamic law. The study discussed Islamic legal maxims in the current context and through the time, which involved the change in 'urf and its benefits.

The study by Norzulaili Binti Mohd Ghazali (2004) looked at the application of several figh methods in the Islamic family law of Malaysia by focusing on Pahang Islamic Family Law Enactment 1987. The study sought to ascertain the extent to which the enactment abides by the current fiqh in specifying any conditions, rules or procedures. The study, which used the library method, found that the content of the enactment does not contradict the Islamic ruling and is in line with Islamic legal maxims such as al-Umūr bi Maqāsidihā, al-'ādah of the Court, al-Darar Yuzāl, al-Darar Yuzāl bi Qadr al-Imkān, and Tasarruf alImām `ala al-Ra iyyah Manūt bi alMaslahah. However, the theoretical discussion of the method of Islamic legal maxims was limited in scope to Pahang Islamic Family Law Enactment only.

Ab Rahman Bin Ismail (2007) conducted a study on the application of the Fiqh Mā Lā Yudrak Kulluh Lā Yutrak Julluh method in classifying Shariah-compliant stocks on Bursa Malaysia. The study gave an insight into the application of the Islamic legal maxim of "what cannot be done entirely should not be abandoned entirely" on Shariah-compliant stocks. It also examined the submissions used by the Securities Commission's Shariah Supervisory Council in classifying each listed security as Shariah-compliant or otherwise. In addition, the study discussed the issue of share business transactions from the Islamic perspective. The results of that study show that mixed companies are required to meet the set criteria. The Islamic legal maxim of "what cannot be done is not necessarily abandoned" can be applied in classifying the halal and illegal elements of mixed companies if they meet the Shariah requirements. The researcher also found that not all share transactions on Bursa Malaysia complied with Islamic 


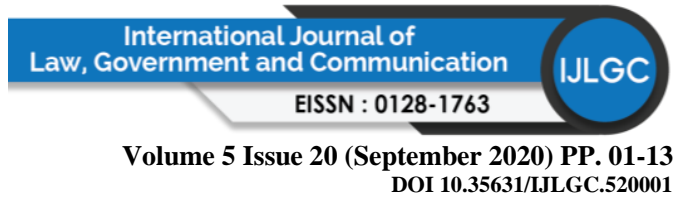

law. However, the study only dealt with the Islamic legal maxim of Mā Lā Yudrak Kulluh Lā Yutrak Julluh, which is used in identifying Shariah-compliant stocks.

The study by Anwar Fakhri Omar (1999) focused on the fiqhiyyah method and its relationship with current fiqh issues. The study used the literature method to examine the extent of the relationship between Islamic legal maxims and the current problems faced by Muslims. The results obtained indicate that an Islamic legal maxim can be used as a direct source or a substitute for a fiqh problem only if it is derived from legal or Islamic sources that have been approved by scholars as in agreement with the Quran, Hadīs, Ijmak, and al-Qiyās, or from the sources of jurisprudence prevailing among the ulama, such as al-Istihsān, al-Masālih alMursalah, al-'Urf, Madhhab al-sahābi, al-Istishāb, and Sadd al-Dharā'. The researcher also discussed the five Islamic legal maxims, but the focus of the analysis was only on current fiqh problems, namely smoking, blood donation, surrogate mother, and transplanted human limb.

Mohd Asri Bin Yaacob (2013) looked at the relationship between the concept of Ihtiyat and the Fiqh Idhā Dāqa al-Amr Ittassa method from the perspective of the Syafie school of thought in the problem of worship. The study also identified the application of the Ihtiyat concept and Fiqh Idhā Dāqa al-Amr Ittassa' method in religious matters based on the Syafie school of thought. The researcher used the library method to collect data for the study, and the Subsequently, the study by Zubir (2008) examined Islamic legal resources and fiqh methods and their relationship in resolving current issues. The study investigated the fundamental development of fiqh and how Islamic legal maxims play a role in solving current issues. The research was done by reviewing past studies of numerous scholars. The results of the study show that although Islamic legal maxims cannot be used as a source of al-Quran and Hadith, these maxims are vital in guiding the mujtahid by ensuring that the development of fiqh does not deflect from the foundation of Islamic law. The study discussed Islamic legal maxims in the current context and through the time, which involved the change in 'urf and its benefits.

The study by Norzulaili Binti Mohd Ghazali (2004) looked at the application of several fiqh methods in the Islamic family law of Malaysia by focusing on Pahang Islamic Family Law Enactment 1987. The study sought to ascertain the extent to which the enactment abides by the current fiqh in specifying any conditions, rules or procedures. The study, which used the library method, found that the content of the enactment does not contradict the Islamic ruling and is in line with Islamic legal maxims such as al-Umūr bi Maqāsidihā, al- 'ādah of the Court, al-Darar Yuzāl, al-Darar Yuzāl bi Qadr al-Imkān, and Tasarruf alImām 'ala al-Ra iyyah Manūt bi alMaslahah. However, the theoretical discussion of the method of Islamic legal maxims was limited in scope to Pahang Islamic Family Law Enactment only.

Ab Rahman Bin Ismail (2007) conducted a study on the application of the Fiqh Mā Lā Yudrak Kulluh Lā Yutrak Julluh method in classifying Shariah-compliant stocks on Bursa Malaysia. The study gave an insight into the application of the Islamic legal maxim of "what cannot be done entirely should not be abandoned entirely" on Shariah-compliant stocks. It also examined the submissions used by the Securities Commission's Shariah Supervisory Council in classifying each listed security as Shariah-compliant or otherwise. In addition, the study discussed the issue of share business transactions from the Islamic perspective. The results of that study show that mixed companies are required to meet the set criteria. The Islamic legal maxim of "what cannot be done is not necessarily abandoned" can be applied in classifying the halal and illegal elements of mixed companies if they meet the Shariah requirements. The 


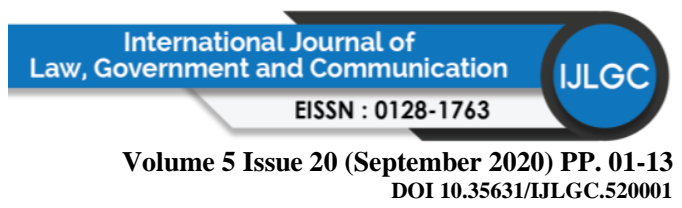

researcher also found that not all share transactions on Bursa Malaysia complied with Islamic law. However, the study only dealt with the Islamic legal maxim of Mā Lā Yudrak Kulluh Lā Yutrak Julluh, which is used in identifying Shariah-compliant stocks.

The study by Anwar Fakhri Omar (1999) focused on the fiqhiyyah method and its relationship with current fiqh issues. The study used the literature method to examine the extent of the relationship between Islamic legal maxims and the current problems faced by Muslims. The results obtained indicate that an Islamic legal maxim can be used as a direct source or a substitute for a fiqh problem only if it is derived from legal or Islamic sources that have been approved by scholars as in agreement with the Quran, Hadīs, Ijmak, and al-Qiyās, or from the sources of jurisprudence prevailing among the ulama, such as al-Istihsān, al-Masālih alMursalah, al-'Urf, Madhhab al-sahābi, al-Istishāb, and Sadd al-Dharā'. The researcher also discussed the five Islamic legal maxims, but the focus of the analysis was only on current fiqh problems, namely smoking, blood donation, surrogate mother, and transplanted human limb.

Mohd Asri Bin Yaacob (2013) looked at the relationship between the concept of Ihtiyat and the Fiqh Idhā Dāqa al-Amr Ittassa method from the perspective of the Syafie school of thought in the problem of worship. The study also identified the application of the Ihtiyat concept and Fiqh Idhā Dāqa al-Amr Ittassa' method in religious matters based on the Syafie school of thought. The researcher used the library method to collect data for the study, and the Nora'inan binti Bahari (2008) examined the application of the al-Darar Yuzāl concept in Islamic family law. The study discussed the maxim of al-Darar Yuzāl in terms of service to the wife in a polygamous marriage, nusyuz or irresponsibility, talak or divorce by tafsir or other similar means, khuluk or divorce by compensation, and fasakh or the dissolution of marriage through judicial means and the maintenance of a diary. The study found that this maxim covers all aspects of family law encompassing before, during, and after the marriage. In addition, this concept is used as the original law in an al-darurah situation to give permission to see the woman to be proposed and also to answer questions related to the original law such as a widow's living allowance.

The above discussion illustrates that many studies have looked at Islamic legal maxims. However, the previous studies were too brief and covered research scopes that are different from the focus of the present study. Hence, this study deals with Islamic legal maxims, specifically on the notion of judgment and performs in-depth analysis of previous research in this field. Thus, this study is a pioneer in research on this particular topic.

\section{Research Methodology}

This study adopted the socio-legal form, which is a research method that unites two key areas of research, namely social science, and law. Since the law is set up as a mechanism for managing the affairs and conflicts that arise in societies, the law has a close and challenging relationship with the community (Rohani Abdul Rahim, 2002). This study also involved systematic research of new and up-to-date legal issues that required authenticity and high creativity through traditional and conventional legal methods by incorporating the process of stating, interpreting, and explaining existing laws (clarifying existing laws) in the legal field (Mahdi Zahraa, 1998).

Data were collected by using the documentation method, which involves examining the documents related to the problem being studied (Abdul Halim bin Mat Diah, 1987). The documents included in the document category are photographs, portraits, results, court 


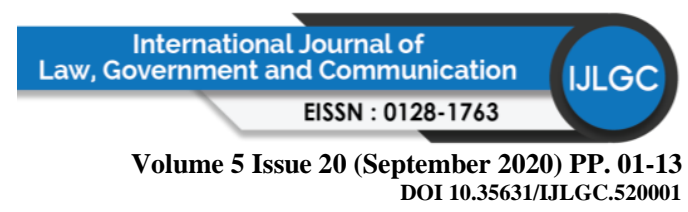

procedures, laws, and regulations (Imam Barnadib, 1982), autobiography, personal papers, diaries, and newspapers (Koentjaraningrat, 1986).

This study also used content analysis to examine the fatwa research methodology for science and technology-based laws. This method requires a particular theme setting in ensuring that the analysis of the text does not involve any mistakes (Muhammad Haji Yusuf, 1993). In this study, the theme is related to the fatwa research methodology for current legal issues. Based on the objective of the study, the documents for content analysis were identified by selecting appropriate texts such as the preferred Islamic legal maxims applied by judges.

The research methodology involved five steps, starting with identifying the problem and followed by selecting the sample, reading and recording the content according to the objective rules, and interpreting the results of the study. The sample of the study included selected fatwa and law used in this study. (Syed Arabi Idid, 1999).

One form of social research is field research based on interviews (Anwarul Yaqin, 2007), which are social interactions aimed at gathering information for research purposes. This study focused on gathering information and researching categories of evidence based on the Islamic Family Law Enactment in Kedah 2008.

This study used both primary data and secondary data. Structured and unstructured interviews were conducted with six experts where two of them were academicians and four were legal practitioners. The interview respondents were selected using the snowball sampling technique to obtain the desired information (Anwarul Yaqin, 2007). They were selected based on their expertise in the field, position in their line of work, and experience. The interviews were conducted over four months from September to December in 2017 in the states of Kedah and Kelantan. Kedah was selected as the state has the latest Islamic family law enactment, which took effect in 2008, while Kelantan was selected due to good track record in governance and management aspects. The interviews questions are original and based on the objectives of the study. All the information of the respondents is confidential. The interviews were recorded, and transcripts processed. Furthermore, books and articles were also referred to as sources of information.

The observation method is one of the ways used to collect data by direct observation the object that is being studied (Samarudin Rejab \& Nazri Abdullah, 1982). Observations are determined by the procedures and realities of the execution taking place on the subject matter. Direct observation, which involves confronting the respondent or target object, can be employed to reach the necessary formulations and conclusions.

\section{Islamic Family Law in Malaysia}

A marriage contract is noble, and its attachment lasts until the end of one's life. It is entirely different from a civil contract, which remains in force only up to the point that both contracting parties fulfil their respective obligation. However, if a marriage had to end after all efforts have been exerted to the best of the parties' ability, then the couple must accept their destiny by dissolving the marriage in accordance with the law.

This is the role of Section 47 of Islamic Family Law Enactment, Kedah 2008, which states that a married couple that wants to apply for a divorce needs to fill in the prescribed form accompanied by an iqrar on matters related to the divorce application, the court which has the 


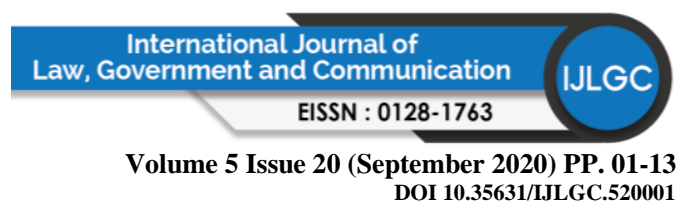

jurisdiction, information related to any previous divorce proceedings involving the couple, information on the efforts undertaken to reconcile, entitlements and benefits promised to the wife and children after the divorce, and any details of the order requested.

Based on the provision of this section, it can be concluded that before the husband pronounces the talak, either one of the spouses must apply for a divorce order from the court. After the court has received the divorce application, the second party will be called to the court for an investigation on whether the divorce application is mutually agreed by the parties. If the second party agrees to the divorce and following the investigation, the court is satisfied that the marriage has ended, then the court will advise the husband to pronounce the divorce before the court. This method is done to ensure that the talak will be pronounced in a controlled, calm, and sane state and not in the mood of anger and chaos. Both parties then need to agree to the talak that will be pronounced, and the court or judge will be the most authoritative witness of the divorce settlement between the parties.

The provisions of this law are in parallel with verse 2, surah al-Talaq of the Qur'an:

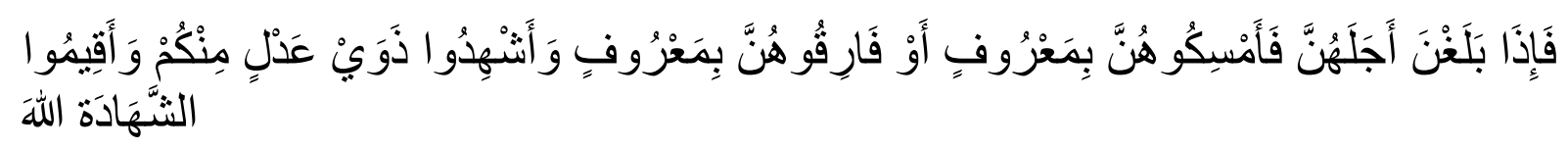

Meaning: "Therefore if they have reached the designated time, take them back well or divorce them in a good way. And witness to two sincere people among you and establish the testimony for God."

The divorce pronouncement using the word talak is as per the word of Allah in surah alBaqarah, verse 229, which reads:

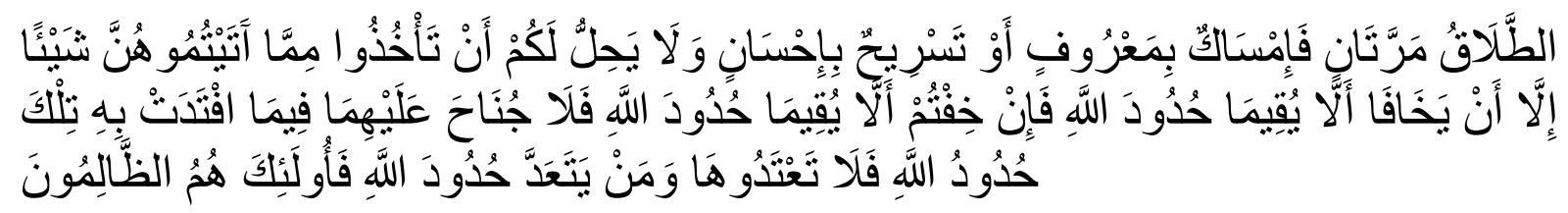

Meaning: "Talak (which can be referred back only) twice. After that he can (refer) and hold on (his wife) in a proper way or let him (divorce him) in a good way."

The divorce pronouncement with saraah (last) is as per the word of Allah in verse 2, surah AlAhzab, which means:

"...and release them in the best possible way."

\section{The Concept of Divorce According to Islamic Law}

The Islamic law on divorce in Malaysia can be seen from two perspectives, namely Islamic law and Malaysian legislation. According to Islamic law, divorce is lawful in Islam but is despised by Allah S.W.T. Therefore, even though divorce is allowed by the religion, it is the last resort after all other means to reconcile the married couple have failed. Thus, a divorce has to be done for the betterment of the parties involved. In this context, the divorce is commonly known as talak from the legal point of Shariah. 


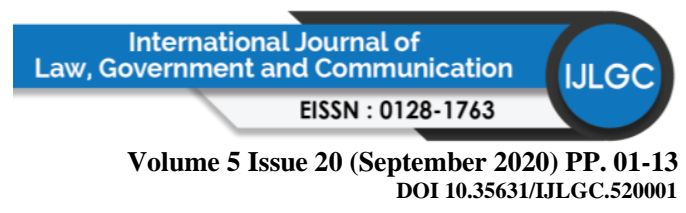

This type of divorce is divided into two categories, namely sorih and kinayah. Sorih happens when the divorce is clearly described in the message uttered and there is no other underlying meaning behind it. The three commonly used terms in the divorce utterance are talak or divorce, free or past, and separate. In contrast, kinayah involves the use of various terms such as free, split, go back to your family, and you are haram to me. These words can be interpreted as talak or otherwise. If the husband deliberately pronounces such terms, then only the husband knows what he means, and he needs to be responsible for his utterance. If the husband pronounces it with any other intention apart from talak or does not intend anything, then the talak is not valid (Muhd Fauzi Muhamad, 2003).

Besides talak, the wife can also seek to dissolve the marriage by applying for fasakh or khuluk. Other types of divorce include taklik, li'an, a spouse leaving Islam, and the assumption of death (Mustafa Al-Khin (Terj.), 2016.)

\section{The Concept of Divorce According to Law}

The history of Islamic law in Malaya began with the Malacca Code of Law, which subsequently influenced the laws in other states. The laws adopted before the arrival of the British were Islamic law mixed with customary law. There were some civil court decisions made during British colonisation that indicated that the Islamic law is not a foreign law but a local law.

When Malaya gained independence from the British in 1957, the Reid Commission under Article 3 of the Federal Constitution gave a position and privilege to Islam; however, Article 160 of the Federal Constitution abrogates the law of Islam in the definition of law (Ahmad Mohamed Ibrahim, 1997).

The jurisdiction of the Shariah Court is provided in the Ninth Schedule, List II (State List) of the Federal Constitution, and the Shariah Court (Criminal Jurisdiction) Act 1965 (Amendment 1984) was specially assigned to the Syariah Courts. In enforcing Islamic law, each state has its own Islamic Religious Administration Enactment. However, the administration of the Shariah Courts was not as satisfactory as that of the Civil Courts. As a result, a committee was established to determine the position, power, and status of each Shariah Court and the Shariah Court judge (Ahmad Ibrahim, 1999).

The dissolution of a marriage affects the husband and wife, starting from the procedure to dissolve the marriage and specify the type of divorce up until the divorce registration is complete. Usually, the husband can apply for a divorce, while the wife can use the method of khuluk, taklik or fasakh to dissolve the marriage. All these methods of marriage dissolution have specific provisions in the Islamic Family Law Enactment of the States. To date, many divorce cases involved the dissolution of marriage. In a case where either party does not agree to dissolve the marriage, a judge may be appointed for the divorce application.

The problems that often arise in divorce cases include the husband ignoring the wife by abandoning her or failing to provide sustenance, the absence of either spouse during the trial, and torture or assault of the wife by the husband, which allows the wife to apply for divorce through taklik or fasakh. The wife can also apply for fasakh in certain circumstances such as the husband's inability to provide sustenance or shelter, insanity, harmful illnesses like leprosy, and obstruction of sexual intercourse due to disability such as genital mutilation or impotence. 


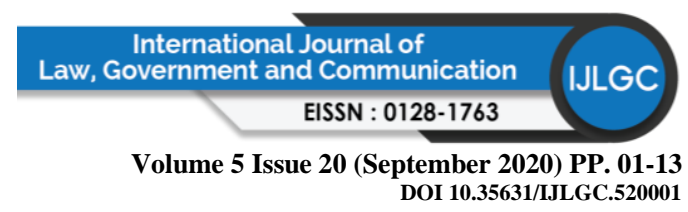

Apart from that, the wife can apply for fasakh if the husband has gone missing and cannot be contacted by any means.

Another problem that exists within the context of marriage dissolution is $l i$ 'an, which refers to the loss of trust between the husband and wife. In this instance, either one of them is willing to swear li'an by giving a statement that one of the parties has been cheating, or the husband has rejected the sworn statement made by the wife.

In addition, a marriage can be dissolved when either spouse leaves Islam or embraces Islam. There are two important issues concerning religious conversion. Firstly, when a non-Muslim husband or wife embraces Islam, the spouse is allowed to file for divorce under the Law Reform (Marriage and Divorce) Act 1976. As long as the non-Muslim spouse does not petition for divorce, then the Muslim spouse cannot ask petition for his marriage in the Shariah Court.

Secondly, when either spouse leaves Islam, the application to dissolve the marriage must be made in accordance with the provisions of the Islamic family law of the state where the couple resides. However, the Shariah Court must first confirm that the spouse has denounced Islam. Whether a Shariah Court or a Civil Court has the jurisdiction to certify a person's decision to leave Islam has been answered in the result of the case of Soon Sing vs Perim and another [1999] 1 MLJ 489. In this case, the Federal Court considered the provisions of Article 121 (1A) of the Federal Constitution and ruled that only a Syariah Court has the jurisdiction to confirm the status of a person leaving Islam in order to embrace another religion.

\section{Talak Outside The Court}

Talak that is pronounced outside the court and without the court's consent is an offence, pursuant to Section 125 of the Kedah State Islamic Family Law Enactment 2008. If convicted, the person who pronounced the talak will be liable to a fine of not more than RM1000 or imprisonment not exceeding six months or both. Although the penalty value is low, the impact on marital status is particularly intense, especially to the wife. Hence, this paper explores and discusses thoroughly the implications that will arise if this matter is not taken seriously, which will then prolong the suffering of the victims, namely the wife and children. Thus, to avoid such occurrence in a marriage, each married couple must understand and familiarise themselves with the provisions of the law so that any action taken on the marriage is in accordance with the legal provisions.

The application to pronounce talak in the court continues to be questioned by sceptical religionists and society, which claimed that it does not abide by the law of Allah as found in al-Qur'an and Al-Sunnah. The practice of pronouncing divorce outside the court also contradicts the law in force in Malaysia. Thus, this paper will highlight the matters that should be understood by the public so that the adverse implications of a divorce can be mitigated, and the divorcees will get their rights fairly and equitably.

\section{The Renewal of Islamic Family Law at the Global Level}

In the Philippines, the first Islamic law recognised in the Philippine legal system is the Code of Muslim Personal Law 1977, which deals with family law and inheritance law. This law came into effect in October 1985. 


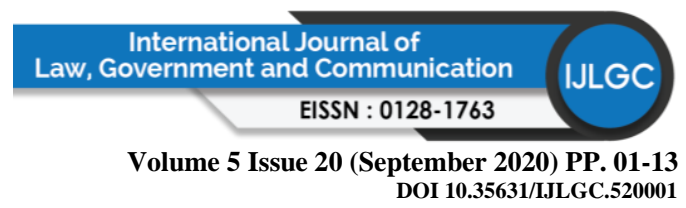

Some Islamic countries have reformed the Islamic family law to suit local circumstances through the modern legal process either by adopting other schools of thought or by administrative regulations. The Islamic countries that fall within this category are Turkey (from 1917), Egypt (1920-1946), Sudan, Jordon, Syria, Tunisia, Morocco, Algeria, Iraq, Iran, and Pakistan. The family law reforms are either 'substantive' or 'administrative' or both, by combining one or more opinions of the fuqahak.

In addition, Muslim countries in Southeast Asia such as Brunei, Malaysia, Indonesia, Singapore, and Ceylon also fall under this category. These countries have formulated a comprehensive Islamic Family Administration Enactment, including the regulation on polygamy and divorce.

\title{
Findings and Analysis
}

This study used the interview method to obtain data on respondents preferred Islamic legal maxims on divorce issues. They were six respondents where two of them were academicians and four were legal practitioners. However, only three of them answered the interview questions on this issue, comprising one academician and two Shariah judges.

The respondents' used preferred Islamic legal maxims are R1, R2 and R3. R1 mentioned as follows:

\begin{abstract}
"Al-Aslu Adam". Originally there was nothing, as long as one thing did not exist, so if it does not fit even "Yaridadalil'ala tayirihi "until there is a proposition to change it. For example, he said these two, the origin of the husband and wife, there is no word for divorce, but there are other parties other than the husband, not the wife, this claims that the word divorce occurs. The nights he heard fights or quarrels, suddenly the word divorce, indeed he heard the word divorce, in the house, so he made an application to confirm. So, the burden of proof is that there are parties who claim to follow Section 72 of the Kelantan State Syariah Court evidence enactment. He in the case of MAL like this burden of proof to the level of "Gholabatuzzon". This "Gholabatuzzon" has reached a stage beyond doubt, not 100 percent sure. The burden of proof on those who claim, for example, in the case of this application for confirmation of divorce, because it happened outside the court, the wife who claimed that the divorce was pronounced, so she has to prove it if this divorce is pronounced via WhatsApp or SMS, before, famous in 2005, he has to prove it. So, the husband also he has to defend. If he admits there is no problem. Because there are half of those who say divorce by SMS, he just wrote and sent. So, the word fall. This friend did not even read, he just wrote and wrote, he did not send, he did not even read, did not fall, he must "Attalafuss" he must say. If he reads it, reads it in his heart, he does not send it, he must say it orally. Because there is a saying said with this SMS, he said then it falls. He has to see who sent it. Like "At-tollak bil kitabah" means he wrote in writing and he sent to his wife, he had to say it too, he had to say it. This word, a word not a word with the lips of the mouth, he has to say it orally, in the least he hears with his own ears.
\end{abstract}




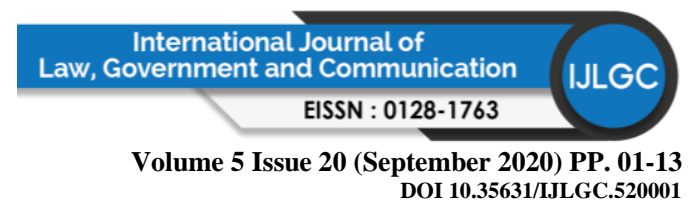

Meanwhile, R2 and R3 explained that:

The method does exist. Therefore, there is a method of saying "tassoroful iman manuthun bil maslahah". It general meaning means; every government action must revolve around the welfare of the people. The meaning must be for the maslahah of the people. So, the aim is to take care of the welfare of the household. Husband and wife who have claimed to have divorced and so on. Make a confirmation. Perhaps, it can lead to evil. Maybe. The Religious Council will confirm the divorce without reference and may even deny the continued occurrence of talak right or finally talak divorce without alimony to everything. Then, will harm the couple, especially the woman. So, to avoid such harm that will probably happen after the unregistered divorce. Therefore, the court must take the responsibility to resolve or confirm and finally prove to confirm so that each of them gets the appropriate rights for the good of their spouses. Thus, the court's action revolves around actions, based on the welfare of the people. "Tassoroful iman manuthun bil maslahah." Because the court means to protect the welfare rights of the people. As for, regarding the method of divorce outside the court, it is not discussed specifically because for us, the court was created after looking at the benefits. Meaning the old days may have been a "personal" divorce. Just meet the priest and say the talak without referring back, without being documented, without being talked about. Use it, believe it. So, the existence of the court is also for maslahah as well. Discuss our divorce issues. Apart from "tassoroful iman manuthun bil maslahah", we also have a method that mentions that "al-aslu al-'adam". "Al-aslu al-'adam" means that the origin does not exist. Meaning, if there is a claim of talak, the meaning is something new with the original meaning that there is no talak. As long as there is no divorce in the household. When claiming a divorce, it means that the marriage has taken place. This is what we need to understand. When the allegation of divorce occurs, it means confident that there is a marriage. When claiming that the original does not exist, for proof, there must be a confession, witness and so on. In the context of the occurrence, the talak of witnessing is ok to convict the talak which originally did not exist. But, if the case does not have a witness, only a confession, the confession is "yes". Confession is also a strong enough evidence for the occurrence of divorce. Even if the husband jokes, the divorce will fall. Moreover, the husband confessed. So, "al-aslu al-'adam" the court must ask the husband to come to court to prove the validity of the talak because there was originally no talak. When lying and so on. "Al-aslu al-'adam". Basically, the origin of something does not exist.

The findings from the interviews show that judges applied and implemented the preferred Islamic legal maxims in their judgments. The preferred Islamic legal maxims consider the Maqasid Al-Shariah values, in parallel with al-Quran and al-Sunnah. The preferred Islamic legal maxims used are "al-aslu al-adam" and "tassoroful iman manuthun bil maslahah". Therefore, this article hopes that society can entrust Maqasid Al-Shariah, given the prevalence of family issues today.

\section{Suggestions}

Firstly, this article affirms that Maqasid Al-Shariah has been used in the Islamic Family Law Enactment as a benchmark in ensuring that the law is in parallel with the Shariah. Hence, 


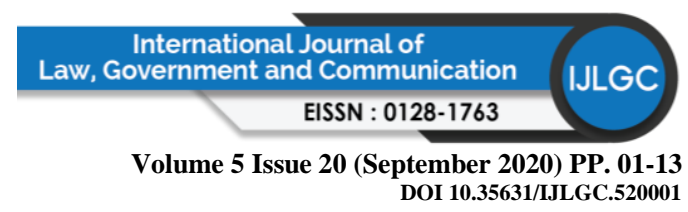

religionists have no basis for arguing that the enactment is not the in line with the Islamic law and Shariah.

Secondly, Shariah judges must apply at least two Islamic legal maxims when deciding a case, especially in the case of talak outside the court. Guidelines need to be drafted and disseminated to all states and must be used by judges in their judgment.

Thirdly, this study suggests that religious groups and communities should be more open to reforms that are taking place on the international plane by considering the interests of society in general.

Fourthly, Shariah judges and lawyers should assist in the development of innovative elements that cover both religious and legal aspects. Such applications and trends will have a tremendous impact on the religious and institutional courts, in particular the Shariah Courts at the national level. These applications are aimed at preventing confusion among the parties involved, specifically the Muslim community.

\section{Conclusion}

This study has provided an in-depth explanation of the role and application of preferred Islamic legal maxims as a legal argument. It is hoped that this study can enhance the community's understanding of Islamic legal maxims and the laws on the problems that are not explicitly stated in al-Quran and Hadith. In addition, the study may provide law practitioners, students, and the community with an insight into the roles of Islamic legal maxims and their application in judgments.

Strong collaboration between religious groups and legal experts are impertinent and should be given priority. With this collaboration, the elements of innovation that combine Islamic law and legislative force can be established without causing contradictions. This collaboration is expected to have a tremendous impact on legislative institutions, especially the Syariah Courts, which will prevent confusion and eliminate misunderstandings among the affected parties in particular and the Muslim community in general. Collaboration and empowerment are crucial ingredients in creatively adapting to the changing times and circumstances.

\section{References}

Al-Quran Al-Karim

Ab Rahman Ismail (2007), "Aplikasi Kaedah Fiqh Mā Lā Yudrak Kulluh Lā Yutrak Julluh Dalam Mengklasifikasi Saham-Saham Patuh Syariah Di Bursa Malaysia”, (Disertasi Ijazah Sarjana, Fakulti Pengajian Islam, Universiti kebangsaan Malaysia.)

Abdul Halim bin Mat Diah. 1987, Suatu Contoh Tentang Huraian Metodologi, Kuala Lumpur: Universiti Malaya.

Al-Qarāfī Shīhab al-Dīn Ahmad ibn Idrīs ibn Abd Rahman al-Sanhajī (2007), Kitāb al-Furūq: Anwār al-Furūq fi Anwā' al-Furūq. j. 1, c. 2, Kaherah: Dār al-Salam, h. 71.

Anwar Fakhri Omar (1999), "Kaedah Fiqhiyyah dan Hubungkaitnya Dengan Permasalahan Fiqh Semasa" (Disertasi Ijazah Sarjana Fakulti Pengajian Islam, Universiti Kebangsaan Malaysia.)

Anwarul Yaqin. (2007). Legal research writing. Malaysia: LexisNexis.

Enakmen Keterangan Mahkamah Syariah (Kedah Darul Aman) 2014.

Enakmen Undang-Undang Keluarga Islam (Kedah Darul Aman) 2008. 


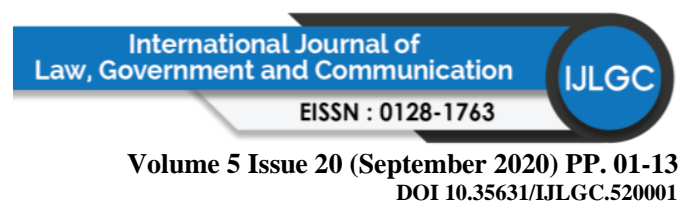

Imam Barnadib. 1982, Arti Dan Metode Sejarah Pendidikan, Yogyakarta: Yayasan Penerbitan FIP-IKIP.

Jalāl al-Dīn `Abd al-Rahman Ibn Abī Bakr al-Suyūṭi (1983), al-Asybāh wa al-Nazā'ir fi Qawā'id wa furu' al-Syāfi'îyyah. Beirut: Dār al-Kutub al-'Ilmiyyah.

Koentjaraningrat (ed.), (1986), Metode-metode Penelitian Masyarakat, Jakarta: Penerbit P.T. Gramedia

Lee Mei Peng, Business Law, Oxford University Press, Selangor, 2011.

Mahdi Zahraa. (1998). Research methods for law postgraduates' overseas students.Univision: Glasgow.

Majallah al-Ahkām al-'Adliyyah. (1968).

Mohd Asri Yaacob (2013), " Hubungkait Antara Konsep Ihtiyat Dan Kaedah Fiqh Idhā Dāqa al-Amr Ittassa' Dari Perspektif Mazhab Syafie Dalam Permasalahan Ibadat”, (Disertasi Ijazah Sarjana Jabatan Fiqh dan Usul, Akademi Pengajian Islam Universiti Malaya.)

Mohd Fauzi Hamat dan Mohd Sobri Ellias (2010), “Aspek-Aspek Pemikiran Kritis dalam alQawā'id al-Fiqhiyyah", Jurnal Syariah, j. 18, Bil. 3.

Muhammad Haji Yusuf (1993). "Hubungan antara Kelompok", dalam Abdul Halim Othman (eds), Psikologi Melayu. Kuala Lumpur: Dewan Bahasa dan Pustaka, Kementerian Pendidikan Malaysia.

Mustāâ Ahmad al-Zarqā' (2001), Syarh al-Qawā'id al-Fiqhiyyah. c. 2, Damsyik: Dār alQalām, h. 42. Muhammad 'Izz al-Dīn 'Abd al-Salām, (t.t.), Qawā'id al-Ahkām fī Masālih al- Anām. Beirut: Dār al-Kutub al-'Ilmiyyah.

Nor Hayati Binti Md Dahlal (2014), “ Penilaian Terhadap Pengurusan Wakaf Di Majlis Agama Islam Kedah (MAIK) Berdasarkan Kaedah Tasarruf al-Imām `Ala alRa`iyyah Manūt Bi al-Maslahah”, (Disertasi Ijazah Sarjana Jabatan Fiqh dan Usul, Akademi Pengajian Islam Universiti Malaya.)

Nora'inan Binti Bahari (2008), “Aplikasi Konsep al-Darar Yuzāl dalam Hukum Kekeluargaan Islam", Jurnal Pengajian Islam, Bil. 3.

Norzulaili Mohd Ghazali (2004), "Aplikasi Beberapa Kaedah Fiqh Dalam UndangUndang Keluarga Islam Malaysia: Satu Kajian Dalam Enakmen Undang-Undang Keluarga Islam Pahang 1987”, (Disertasi Ijazah Sarjana, Fakulti Pengajian Islam, Universiti kebangsaan Malaysia.)

Rohani Abdul Rahim. (2002). Metodologi Penyelidikan Undang-undang: Satu Tinjauan Kepada Kajian Sosio-Perundangan. Seminar Kemantapan Akademik UKM.

Rohani Binti Desa (2012), “Aplikasi Kaedah al-Darurah Dalam Perkhidmatan Kesihatan Di Malaysia”, (Tesis Ijazah Doktor Falsafah, Jabatan Fiqh dan Usul, Akademi Pengajian Islam Universiti Malaya.)

Samarudin Rejab \& Nazri Abdullah. 1982, Panduan Menulis Tesis, Kuala Lumpur: Dewan Bahasa dan Pustaka.

Syed Arabi Idid (1999). Analisa Kandungan. Bangi: Jabatan Komunikasi UKM.

Tāj al-Dīn al-Subkī (t.t.), al-Asybāh wa al-Nazā'ir. j. 1, Kaherah: Dār al-Kutub al-`Arabiy

Zayn al-'Ābidīn Ibn Ibrāhīm Ibn Nujaym (1968), al-Asybāh wa al-Nazā’ir `ala Madhhab Abi Hanifah al-Nu`man. Kaherah: Muassasah al-Halabī.

Zubir (2008), "Sumber Perundangan Islam Dan Kaedah Fiqh Serta Hubungan Keduaduanya Dalam Menyelesaikan Beberapa Persoalan Semasa”, (Disertasi Ijazah Sarjana Sastera, Pusat Pengajian Ilmu Kemanusiaan, Universiti Sains Malaysia.) 